Original Research Paper

\title{
Sosialisasi Pendampingan Asupan Gizi Atlet Muda di Kota Palangka Raya pada Masa Pandemi Covid-19
}

\author{
Yudo Harvianto $^{1}$, Nune Wire Panji Sakti ${ }^{2}$ \\ ${ }^{1}$ Pendidikan Jasmani, Kesehatan dan Rekreasi, Universitas Palangka Raya, Palangka Raya, Indonesia \\ ${ }_{2}^{2}$ Pendidikan Olahraga, Universitas Pendidikan Mandalika, Mataram, Indonesia
}

https://doi.org/10.29303/jpmpi.v3i2.851

Sitasi: Harvianto, Y., \& Sakti, N. W. P. (2021). Sosialisasi Pendampingan Asupan Gizi Atlet Muda di Kota Palangka

Raya pada Masa Pandemi Covid-19. Jurnal Pengabdian Magister Pendidikan IPA, 4(3)

Article history

Received: 05 Juli 2021

Revised: 19 Juli 2020

Accepted: 30 Juli 2021

*Corresponding Author: Yudo Harvianto, Pendidikan Jasmani, Kesehatan dan Rekreasi, Universitas Palangka Raya, Palangka Raya, Indonesia; Email: yudo@fkip.upr.ac.id

\section{Pendahuluan}

Manusia pada secara fitrahnya merupakan kolaborasi antara unsur jasmani dan rohani. Sehingga kedua faktor tersebut tidak bisa terpisahkan pada diri manusia. Sebab keduanya haruslah menjadi satu kesatuan yang wajib dipenuhi oleh setiap manusia. Maka hendaknya kedua faktor ini dijaga dengan sebaik mungkin oleh
Abstract: For an athlete to get a complete nutritional intake with the right portion of food, will make the athlete's body can function to the maximum, so that performance will also be maximal when doing competitions. Therefore, it is important for an athlete to really attention to his nutritional intake, especially the balance between nutritional intake and energy expenditure, both in the phase before, during, and after a match or exercise. Because energy will affect the performance of athletes, as well as the maximum performance of athletes will support it to achieve the best achievement. Especially with the current covid-19 outbreak. The purpose of this dedication is that athletes can find their best diet to improve the efficiency of the body's metabolism to face exercise and matches. The method carried out in this activity is socialization. The implementation of this activity is conducted face-to-face.Participants in this activity are young athletes who are in the city of Palangka Raya with a total of 15 people from various sports including badminton, soccer, volleyball, athletics (sprint), athletics (fast walking), athletics (reject bullets), table tennis, karate, sepak sawut. Based on the results obtained from this activity, there are several problems including the knowledge of athletes about the importance of setting the nutritional intake of sports is still relatively low, the lack of varied food menu consumed, the use of supplements by athletes are too excessive. Then after being able to know about the problem, the presenter gave direction to the athletes to be able to minimize the problem.After the implementation of this activity, the athletes get education regarding nutrition assistance, maximizing the performance of athletes through a diet that suits nutritional needs.As well as education and solutions related to improved performance. The conclusion of this activity is to provide education on nutrition assistance for young athletes in Palangka Raya City.

Keywords: Nutrition, Athletes, Covid-19

tiap individu. apabila didalam diri manusia memiliki jasmani yang bugar serta rohani yang bersih maka dapat tercapai individu yang ideal didalam dirinya. Terlebih bagi seorang seorang atlet, tentunya haruslah memiliki kebugaran jasmani yang baik agar performa menjadi maksimal disaat bertanding salah satu faktor yang mempengaruhi kebugarann jasmani seseorang yaitu asupan gizi (Harvianto, 2020). Menurut (Irianto, 2019) gizi diartikan sebagai proses organisme menggunakan 
makanan yang dikonsumsi secara normal melalui proses pencernaan, penyerapan, transportasi, penyimpanan, metabolisme, dan pengeluaran zat gizi untuk mempertahankan kehidupan, pertumbuhan dan fungsi normal organ tubuh serta untuk menghasilkan tenaga. Sedangkan menurut (Almatsier, 2009) zat-zat gizi yang dapat memberikan energi adalah karbohidrat, lemak, dan protein, oksidasi zat-zat gizi ini menghasilkan energi yang diperlukan tubuh untuk melakukan kegiatan atau aktivitas. Begitu juga menurut Undang-undang Nomor 36 Tahun 2009 Bab VIII pasal 141 ayat 1 dan 2 menjelaskan bahwa Upaya perbaikan gizi masyarakat ditujukan untuk peningkatan mutu gizi perseorangan dan masyarakat. Serta Peningkatan mutu gizi sebagaimana dimaksud diatas dilakukan melalui: a.perbaikan pola konsumsi makanan yang sesuai dengan gizi seimbang; b.perbaikan perilaku sadar gizi, aktivitas fisik, dankesehatan; c.peningkatan akses dan mutu pelayanan gizi yang sesuai dengan kemajuan ilmu dan teknologi; dan d.peningkatan sistem kewaspadaan pangan dan gizi.

Perlu diketahui bahwa bentuk Upaya perbaikan gizi untuk para atlet di Indonesia juga perlu dilakukan, hal ini telah diatur dalam Keputusan Menteri Ketenagakerjaan Republik Indonesia Nomor 156 Tahun 2019 di mana seorang tenaga gizi memilik tugas untuk melakukan pengkajian gizi, diagnosis gizi, intervensi gizi, serta monitoring dan evaluasi intervensi gizi olahraga untuk mencapai prestasi sesuai standar asuhan gizi yang berlaku. Salah satu faktor penting pendukung guna mendapatkan performa yang maksimal disaat bertanding olahraga adalah asupan gizi. Sebab proses metabolisme dalam tubuh manusia membutuhkan gizi. Terlebih apabila seorang atlet mendapatkan asupan gizi lengkap dengan porsi makanan yang tepat, akan membuat tubuh atlet tersebut dapat berfungsi secara maksimal, sehingga performa juga akan maksimal disaat melakukan pertandingan. Oleh karenanya, penting bagi seorang atlet untuk benar-benar memperhatikan asupan gizinya, terutama keseimbangan antara asupan gizi dengan pengeluaran energi, baik pada fase sebelum, saat, dan setelah melakukan pertandingan atau latihan. Karena asupan gizi atlet haruslah sesuai dengan karakterisitik atau cabang olahraga yang digeluti. Sebab setiap cabang olahraga memiliki karakteristik masing-masing serta keperluan energi yang berbeda-beda pula guna meningkatkan performanya. Sebab energi akan mempengaruhi performa atlet, serta performa yang maksimal dari atlet akan mendukungnya untuk mencapai prestasi terbaik. Terlebih dengan adanya wabah covid-19 saat ini. Maka setiap atlet dianjurkan untuk benarbenar memperhatikan asupan gizinya guna meriah performa yang maksimal disaat bertanding.

Berdasarkan latar belakang inilah, penulis mengadakan kegiatan pengabdian kepada masyarakat tentang "Sosialisasi Pendampingan Asupan Gizi Bagi Atlit Muda di Kota Palangka Raya pada Masa Pandemi Covid-19". Tujuan dari pengabdian ini yaitu atlet dapat menemukan pola makan terbaiknya guna meningkatkan efisiensi metabolisme tubuh untuk menghadapi latihan dan pertandingan.

\section{Metode}

Pelaksanaan kegiatan ini dilakukan secara tatap muka. Target peserta dalam kegiatan ini yaitu para atlet muda yang berada di kota Palangka Raya. Atlet yang telah diundang untuk menghadiri kegiatan ini yaitu sebanyak 22 orang. Hal ini dikarenakan masih mempertimbangkan pembatasan kegiatan yang dilakukan masyarakat selama wabah COVID-19 masih terjadi. Sehingga dalam pelaksanaan kegiatan ini, dilakukan dengan mengikuti aturan yang dikeluarkan pemerintah, yaitu dilakukan sesuai dengan protokol kesehatan. Dalam pelaksanaannya, peserta yang bisa menghadiri kegiatan ini yaitu 15 dari 22 orang yang telah diundang. Peserta merupakan atlet dari berbagai cabang olahraga diantaranya, atlet Bulutangkis, Sepak Bola, Bola Voli, Atletik (Sprint), Atletik (Jalan Cepat), Atletik (Tolak Peluru), Tenis Meja, Karate, Sepak Sawut.

Metode yang dilakukan dalam kegiatan ini yaitu sosialisasi. Sosialiasi dilakukan selama satu hari. Didalam kegiatan sosialisasi ini materi yang disampaikan berpedoman pada panduan dari Kementerian Kesehatan Republik Indonesia yaitu tentang Panduan Pendamping Gizi pada Atlet (Kesehatan, 2021b). Selain itu juga dijelaskan tentang panduan berlatih olahraga ditengah pandemi covid-19. Setelah materi dijelaskan maka dilakukan diskusi secara aktif antara pemateri dan peserta dalam sesi tanya jawab. Hal ini dilakukan guna menjelaskan selama mendalam kepada peserta 
apabila ada yang kurang dimengerti, dari materi yang telah dijelaskan. Pelaksanaan kegiatan ini dilakukan di Fitness Center JUARA, pada hari Selasa, 25 Mei 2021. Dari Pukul 07.30 - 11.00 WIB.

Tabel 1. Susunan Acara Sosialisasi

\begin{tabular}{|c|l|}
\hline No & \multicolumn{1}{|c|}{ Agenda } \\
\hline 1 & Registrasi Peserta \\
\hline 2 & Pembukaan \\
\hline 3 & Penyampaian kegiatan \\
\hline 4 & Penyampaian Prosedur \\
\hline 5 & Materi: Panduan Pendamping Gizi pada Atlet \\
\hline 6 & Tanya Jawab \\
\hline 7 & Istirahat \& Penutup \\
\hline
\end{tabular}

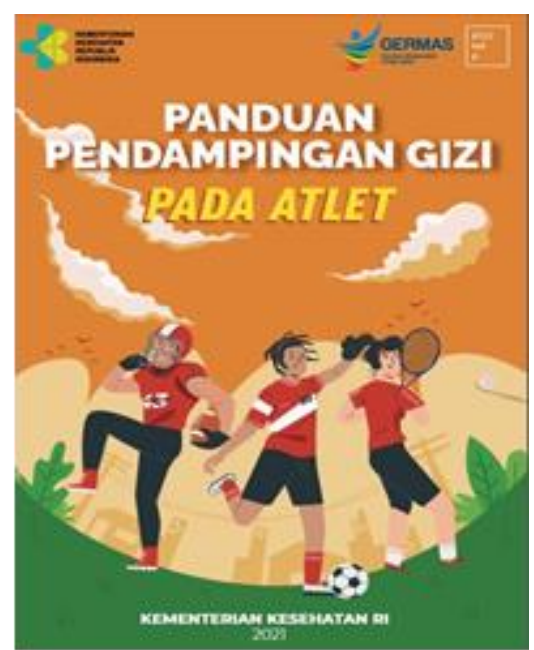

Gambar 1. Sampul Materi

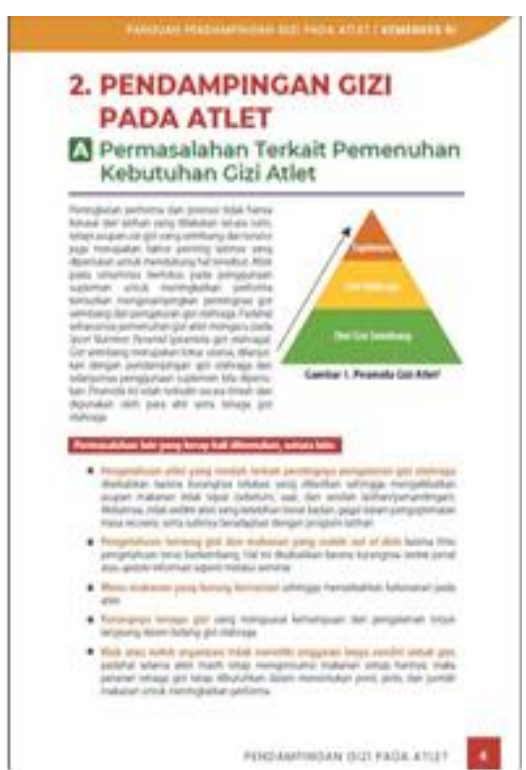

Gambar 2. Materi tentang permasalahan pemenuhan gizi

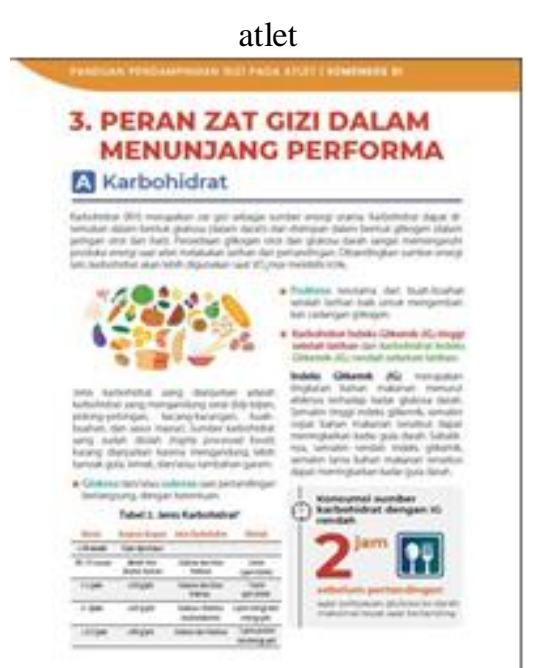

Gambar 3. Materi tentang Peran Gizi dalam penunjang performa atlet

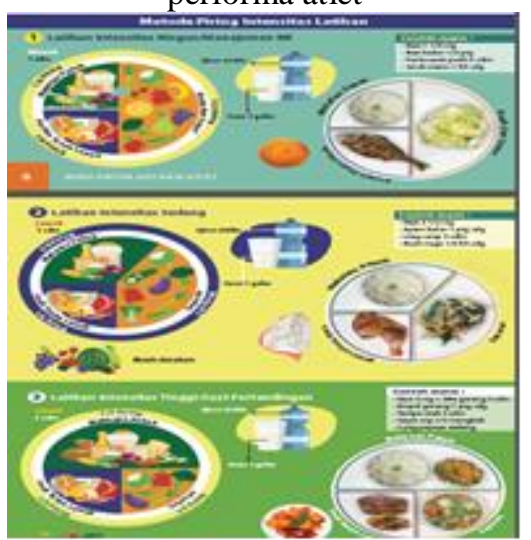

Gambar 4. Metode piring dalam intensitas Latihan

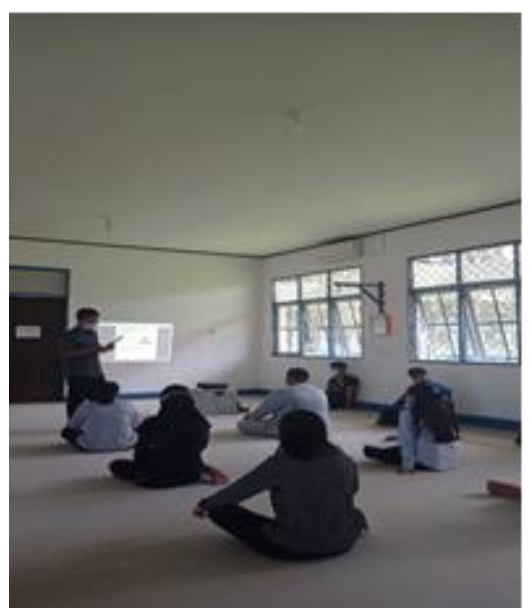

Gambar 5. Penyampaian materi 


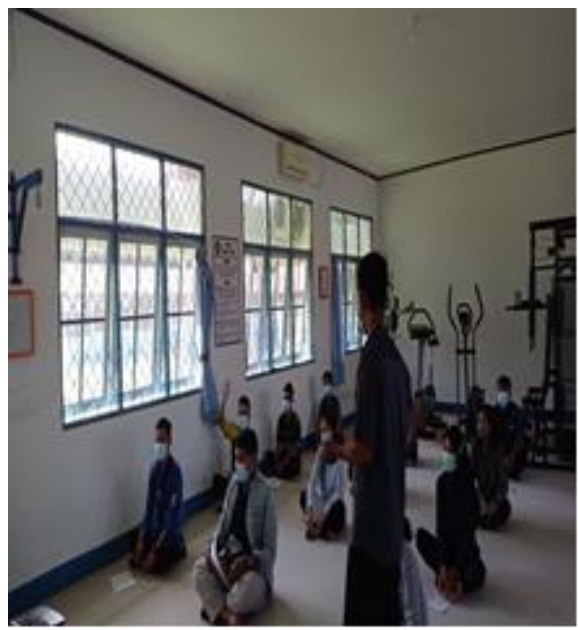

Gambar 6. Sesi Tanya Jawab

\section{Hasil dan Pembahasan}

Dalam peningkatan performa atlet guna mencapai prestasi yang ditargetkan, tidak hanya dibutuhkan program latihan secara rutin dan aspek psikologi (Harvianto, 2019), akan tetapi harus juga dibarengi dengan pendukung lainnya. Salah satu pendukung lainnya tersebut yaitu asupan gizi seimbang. Pemenuhan gizi seimbang pada diri seorang atlet hendak mengacu pada Sport Nutrition Pyramid atau Piramida gizi olahraga (Kesehatan, 2021a). Gizi yang seimbang bagi seorang atlet merupakan faktor utama yang harus dipenuhi, selanjutkan pendampingan gizi kemudian penggunaan suplemen apabila diperlukan.

Berdasarkan hasil yang didapatkan dari kegiatan ini, terdapat beberapa permasalahan yang perlu diberikan solusi. Hal ini dapat diketahui dari hasil diskusi yang dilakukan. Permasalahan tersebut diantaranya yaitu pengetahuan atlet tentang pentingnya pengaturan asupan gizi olahraga masih relatif rendah. Hal ini disebabkan karena minimnya informasi yang diberikan kepada mereka, sehingga seringkali mereka melakukan asupan makanan yang kurang tepat, seperti sebelum, saat dan setelah pertandingan/latihan berlangsung.

Akibatnya tidak sedikit para atlet yang gagal dalam mengoptimalkan performa disaat bertanding atau latihan, dikarenakan misalnya 30 menit sebelum pertandingan mengkonsumsi menu makanan begitu banyak, atau sebelum pertandingan tidak mengkonsumsi makanan sedikitpun. Padahal salah satu faktor yang dapat mempengaruhi prestasi atlet yaitu terkait dengan pengaturan asupan gizi(Surbakti, 2010).
Kemudian permasalahan lainnya yaitu kurang bervariasinya menu makanan yang dikonsumsi. Hal ini boleh jadi terjadi karena salah satu faktornya yaitu dari segi perekonomian. Dengan aktivitas berat yang dilakukan oleh seroang atlet baik disaat berlatih terlebih bertanding. Tentunya akan membutuhkan energi yang cukup besar untuk mengoptimalkan performa yang ada, namun energi ini juga dihasilkan dari menu makanan apa yang dikonsumsi atlet tersebut, apabila menu makanan yang disajikan atau dikonsumsi memiliki variasi asupan gizi, maka energi yang dihasilkan akan bagus, namun sebaliknya apabila menu makanan yang dikonsumsi tidak bervariasi asupan gizi, maka energi yang dihasilkan tidak optimal. Terlebih apabila makanan yang dikonsumsi tidak bervariasi, ada kejenuhan untuk menghabiskannya, sehingga asupan gizi yang diperlukan untuk pengganti energi yang telah dikeluarkan tidak berjalan secara optimal (Inten \& Permatasari, 2019). Oleh karena nya asupan gizi sangat besar pengaruhnya terhadap seberapa besar energi yang kita miliki.

Permasalahan lainnya yaitu penggunaan suplemen oleh atlet yang terlalu berlebihan, untuk mengganti pengaturan pola makanan yang tepat. Hal ini akan mengganggu bahkan membahayakan bagi performa seorang atlet. Terlebih apabila penggunaan suplemen yang berlebihan tersebut tanpa dilandasi dengan adanya indikasi medias atau dasar ilmiah yang valid. Padahal pada hakikatnya mengkonsumsi suplemen untuk melengkapi nutrisi, bukan untuk menggantikannya (B. S. et al., 2020) . Setelah dapat diketahui perihal permasalahan yang ada, pemateri memberikan nasihat dan arahan kepada para atlet untuk dapat meminimalisir permasalahan yang ada.

Setelah terlaksananya kegiatan ini, para atlet mendapatkan edukasi perihal pendampingan gizi bagi para atlet. Selain itu juga, dengan adanya kegiatan ini para atlet mendapatkan edukasi tentang pemaksimalan performa atlet melalui pola makan yang sesuai dengan kebutuhan gizi. Serta dengan adanya kegiatan ini, atlet dapat mengetahui perhitungan pola makan, sehingga dapat dilakukan pengaturan konsumsi makanan bergizi sesuai dengan kebutuhan. Kemudian dengan diadakannya sesi tanya jawab dalam kegiatan ini, atlet dapat menceritakan masalah yang selama ini dialami terkait asupan gizi. Sehingga dengan sesi tanya jawab ini, para atlet mendapatkan edukasi dan 
solusi dari permasalahan terkait dengan peningkatan performa, seperti agar tidak mudah cedera , meningkatkan kebugaran agar tidak mudah lelah, program latihan dan asupan gizi yang sesuai.

\section{Kesimpulan}

Berdasarkan kegiatan pengabdian pada masyarakat yang telah dilakukan ini, dapat disimpulkan bahwa kegiatan sosialisasi pendampingan asupan gizi atlet muda di kota Palangka Raya pada masa pandemi covid-19 ini, dapat memberikan edukasi perihal pendampingan gizi bagi para atlet. Hal ini dapat terlihat pada jawaban lembar tanggapan yang mereka tulis. lanjutnya.

\section{Daftar Pustaka}

Almatsier, S. (2009). Ilmu gizi dasar. In PT Gramedia Pustaka Utama, Jakarta.

B. S., I. N., F. A, A., R., C., Ayu S., D., K, F., Fitria, F., N. E. S., H., A. N. U., H., N, S., A. D., W., A, Y., \& Rahem, A. (2020). Hubungan Usia Dengan Pengetahuan Dan Perilaku Penggunaan Suplemen Pada Mahasiswa Institut Teknologi Sepuluh Nopember. Jurnal Farmasi Komunitas, 7(1), 1. https://doi.org/10.20473/jfk.v7i1.21657

Harvianto, Y. (2019). Minat Partisipasi Dalam Olahraga Ditinjau Dari Suku Bangsa Pada Siswa Di Kota Palangka Raya. JUPE: Jurnal Pendidikan Mandala, 4(4), 17. https://doi.org/10.36312/jupe.v4i4.674

Harvianto, Y. (2020). Kebugaran Jasmani (Y. Wisman (ed.); 1st ed.). K-Media.

Inten, D. N., \& Permatasari, A. N. (2019). Literasi Kesehatan pada Anak Usia Dini melalui Kegiatan Eating Clean. Jurnal Obsesi: Jurnal Pendidikan Anak Usia Dini, 3(2), 366. https://doi.org/10.31004/obsesi.v3i2.18 8

Irianto, D. (2019). Panduan Gizi Lengkap Keluarga dan Olahragawan. Andi.

Kesehatan, K. (2021a). Buku pintar gizi bagi atlet (1st ed.). Kementerian Kesehatan
RI. Direktorat Jenderal Kesehatan Masyarakat.

Kesehatan, K. (2021b). Panduan Pendampingan Gizi Pada Atlet (1st ed.). Kementerian Kesehatan RI. Direktorat Jenderal Kesehatan Masyarakat. https://isbn.perpusnas.go.id/Account/Se archBuku?searchTxt=978-623-301-1082\&searchCat=ISBN\%0Ahttp://perpusta kaan.kemkes.go.id/

Surbakti, S. (2010). Asupan Bahan Makanan Dan Gizi Bagi Atlet Renang. Jurnal Ilmu Keolahragaan, 8(2), 108-122. 